\title{
KONTRIBUSI KREATIVITAS DAN SUVERVISI KEPALA SEKOLAH TERHADAP KINERJA GURU SMP NEGERI PALUPUH KABUPATEN AGAM
}

\author{
Oleh: Yunisrul \\ Email: yunisrulpgsd@yahoo.com \\ FIP Universitas Negeri Padang
}

\begin{abstract}
Teachers have important roles to accomplish the educational goals, and they are expected to show a high level of performance. Performance of the teachers' was presumably influenced by various factors, such as creativity of teachers and principal supervision. Based on a preliminary field observation, the researcher noticed that High School teachers' profesionalism in Palupuh Agam was unsatisfactory.

Applying a stratified propotional random sampling technique, 30 teachers were selected as the research sample from a population of 62 teachers. A Likert scale model questionnaire was developed to collect data whose validity and reliability had been tested. The data were then analyzed by means of correlation and regression statistical procedures.

The result of data analysis indicates that (1) the creativity has contribution as much as $19,6 \%$ of teachers' performance (2) principal supervision contribute as much as 16,6\% and (3) the creativity of teacher and prinsipal supervision either joint 16,7\% of teacher's performance. While the achievement level of creativity, teacher's performance, principal supervision variable are very good.
\end{abstract}

Keywords: Kontribusi, Kreativitas, Suvervisi, Kepala Sekolah, Kinerja Guru

\section{PENDAHULUAN}

Era globalisasi dan reformasi serta kemajuan ilmu dan teknologi yang terjadi begitu cepat menyebabkan tantangan dunia pendidikan semakin berat dan kompleks. Dunia pendidikan hendaklah responsif terhadap perubahan, yaitu dengan memanfaatkan kemajuan teknologi, agar dapat menyesuaikan diri dengan kemajuan zaman. Upaya peningkatan mutu pendidikan haruslah dilakukan dengan terencana dan sistematis, guna menghasilkan sumber daya manusia yang berkualitas dan masyarakat belajar (learning society).

Untuk terselenggaranya pendidikan yang berkualitas pemerintah telah mengeluarkan kebijakan dalam bentuk perangkat Undang-undang Sistem Pendidikan Nasional (USPN) yang mengatur standar kualitas pelayanan, proses, tenaga pendidik, fasilitas dan lulusan. USPN No. 20/2003 menegaskan bahwa pendidikan nasional berfungsi mengembangkan kemampuan dan membentuk watak serta peradaban bangsa yang bermartabat dalam rangka mencerdaskan kehidupan bangsa, bertujuan untuk berkembangnya potensi peserta didik agar menjadi manusia yang beriman dan bertakwa kepada Tuhan Yang Maha Esa, berakhlak mulia, sehat, berilmu, cakap, kreatif, mandiri, dan menjadi warga negara yang demokratis serta bertanggung jawab.

Pendidikan merupakan proses yang sangat komplek melibatkan semua unsur sekolah, masyarakat dan pemerintah. Sebagai sistem, keberhasilan sekolah sangat tergantung dari kondisi internal atau sub-sub sistem yang terlibat secara fungsional yaitu guru, kurikulum, fasilitas dan dana. Secara eksternal, sekolah dipengaruhi oleh supra-sistem seperti kondisi ekonomi, sosial, budaya dan politik. Memang permasalahan pendidikan tidak pernah berdiri sendiri, karena masalah pendidikan tidak dapat diselesaikan oleh kalangan pendidikan saja. 
Pendidikan bertujuan untuk memberikan bekal kemampuan dasar kepada peserta didik untuk mengembangkan kehidupannya sebagai pribadi, anggota masyarakat, warga negara, dan umat manusia serta mempersiapkan peserta didik untuk mengikuti pendidikan menengah atas (PP No. 28/1990), sehingga dalam penyelenggaraan pendidikan dasar, sekolah dikembangkan untuk menjadi lembaga yang berperan dalam pertumbuhan dan perkembangan peserta didik.

Keberhasilan fungsi dan tujuan pendidikan sangatlah ditentukan oleh para pendidik. Guru harus mampu melaksanakan peranannya dalam menjawab tantangan masalah yang dihadapi dalam tugasnya. Ketepatan ini sangat penting karena situasi pendidikan itu tidak dapat terulang kembali secara persis, jadi hanya berlangsung sekali saja. Jika respon yang diberikan keliru, maka guru akan kehilangan waktu yang sangat berharga dalam proses pendidikan yang menjadi tanggung jawabnya dan akan merugikan peserta didik.

Peranan guru dalam keseluruhan program pendidikan di sekolah untuk mencapai tujuan pendidikan secara optimal sangat dominan, yaitu dalam upaya mendidik, membina, dan mengembangkan potensi peserta didik. Guru perlu menentukan pengajaran, materi yang cocok dan sesuai dengan kemampuan siswa untuk mencapai tujuan yang telah dirumuskan.

Guru sebagai pendidik diharapkan mempunyai citra yang baik di mata peserta didik, ia dapat memperlihatkan kelayakannya menjadi panutan atau teladan bagi peserta didik dan lingkungannya. Jika yang ditemukan di lapangan adanya guru yang menjalankan tugas sebagai kegiatan rutin saja, maka hal ini akan mengakibatkan peserta didik dan lingkungan menjadi tidak siap menghadapi segala perkembangan dan perubahan dewasa ini. Oleh sebab itu upaya pengembangan sekolah seyogyanya ditekankan pada guru.

Guru dapat melaksanakan berbagai macam kegiatan demi mencapai tujuan pendidikan yang telah dirumuskan. Untuk mencapai tujuan tersebut guru dapat berperan sebagai pembimbing, pembaharu, model, contoh, penyelidik, konselor, pencipta yang mengetahui sesuatu, pembangkit pandangan, pembawa cerita atau seorang aktor Imron, (1995:4). Semua peran yang telah disebutkan akan dapat membantu guru melaksanakan perubahan, memutakhirkan kemampuannya, agar tidak ketinggalan dengan perkembangan ilmu pengetahuan dan teknologi.

Betapapun bagusnya pembangunan dan pembaruan konsep-konsep program sekolah, namun semua itu tidak merupakan jaminan tercapainya tujuan sekolah bila tidak diikuti dengan peningkatan kemampuan berfikir guru secara kreatif. Oleh karena itu, upaya menumbuh kembangkan dan mendapat perhatian semua pihak, agar guru-guru berfikir mandiri dan dapat menyalurkan fikirannya secara kreatif untuk mengembangkan alternatif penyelenggaraan proses pembelajaran yang menarik dan menyenangkan.

Berdasarkan pengamatan dan wawancara yang telah dilakukan selama prasurvey pada SMP Negeri Kecamatan Palupuh ditemukan beberapa fenomena bahwa gejala-gejala kerja yang belum memadai bahkan cendrung rendah, Guru belum mampu untuk mengambil kebijakan dalam melaksanakan tugasnya untuk menghadapai tantangan perubahan yang disebabkan kemajuan zaman dan menutut inovasi pendidikan agar tidak ketinggalan zaman.

Guru memiliki sifat tidak peduli terhadap setiap perubahan yang terjadi. Seorang guru dalam melaksanakan tugasnya memiliki rasa tanggung jawab yang baik terhadap siswa, menyediakan waktu dan kesempatan untuk membina siswa yang mengalami kesulitan belajar, memiliki loyalitas yang tinggi, baik kepada tugas maupun terhadap sekolah dan pimpinan. Keberhasilan guru dalam melaksanakan tugas yang diberikan kepadanya ditentukan oleh para guru.Guru perlu menentukan materi pengajaran yang cocok, sesuai dengan kemampuan siswa untuk mencapai tujuan yang telah dirumuskan.

Terkesan guru belum mau melakukan, memperbaiki terhadap pelaksanaan kegiatan belajar mengajar yang mereka tampilkan. Hal ini terlihat 
dari cara, strategi atau alat yang digunakan masih belum diperbaharui, meskipun mereka sudah diberi pelatihan atau penataran. Dalam menyajikan pelajaran ada guru yang tidak membuat rencana dan satuan pembelajaran dalam mengajar. Guru belum seluruhnya melakukan analisis hasil pembelajaran dan belum memanfaatkan sarana pembelajaran secara optimal. Guru cenderung menggunakan pendekatan pembelajaran yang monoton tidak berubah dari waktu ke waktu. Hal ini memperlihatkan penggunaan media dan metode mengajar yang cenderung sama dari tahun ke tahun, tanpa adanya kreasi baru. Disamping itu, mereka tidak mempunyai kepedulian untuk mau terlibat dengan persoalan yang dihadapi teman sejawat.

Berdasarkan uraian yang telah dikemukakan di atas peneliti merasa perlu untuk mengadakan penelitian tentang faktor-faktor yang berhubungan atau ada kaitannya dengan kinerja Guru, karena guru adalah ujung tombak dari keberhasilan pendidikan, juga untuk meningkatkan kualitas hasil belajar siswa.

Berdasarkan identifikasi dan pembatasan masalah di atas, masalah penelitian ini dapat dirumuskan sebagai berikut:

1. Apakah Kreativitas berkontribusi terhadap kinerja guru SMP Negeri Kecamatan Palupuh?

2. Apakah Supervisi berkontribusi terhadap Kinerja guru SMP Negeri Kecamatan Palupuh?

3. Apakah Kreativitas dan Supervisi secara bersama-sama berkontribusi terhadap Kinerja guru SMP Negeri Kecamatan Palupuh?

Sejalan dengan perumusan masalah penelitian di atas, maka tujuan penelitian adalah untuk mengungkapkan:

1. Kontribusi Kreativitas terhadap Kinerja guru SMP Negeri Kecamatan Palupuh

2. Kontribusi supervisi terhadap Kinerja guru SMP Negeri Kecamatan Palupuh

3. Kontribusi Kreativitas dan supervisi secara bersama-sama Kinerja guru SMP Negeri Kecamatan Palupuh.

Hasil penelitian ini diharapkan dapat bermanfaat bagi:
1. Guru SMP Negeri Kecamatan Palupuh sebagai bahan masukan untuk melakukan perubahan dengan gagasan dan ide yang lebih baik serta melakukan terobosan yang baru untuk meningkatkan pelaksanaan tugas guru , pembelajaran yang lebih efektif dan bermutu.

2. Kepala SMP sebagai bahan pemikiran dan pertimbangan dalam pengembangan manajemen SMP Negeri Kecamatan Palupuh

3. Kepala Dinas Pendidikan dan Pengawas SMP sebagai bahan masukan untuk melakukan pembinaan terhadap upaya pengembangan Kinerja guru -guru SMP Negeri Kecamatan Palupuh

4. Peneliti mengharapkan bahan acuan dalam membina dan mempersiapkan langkahlangkah pengembangan Kinerja guru ke depan.

\section{METODE PENELITIAN}

Pengambilan sample dalam penelitian ini dengan menggunakan teknik Stratified proportional random sampling. Teknik ini akan menghasilkan sampel sesuai dengan proporsi dari setiap kelompok strata populasi. Teknik ini juga dapat memberi peluang yang sama kepada semua anggota untuk menjadi anggota sample yang representatif. (Arikunto, 1987:111)

Strata populasi yang dipertimbangkan dalam pengambilan sampel adalah tingkat pendidikan, masa kerja. Penetapan strata populasi dilakukan dengan asumsi bahwa strata tersebut diperkirakan berpengaruh terhadap kinerja guru. Tingkat pendidikan terdiri dari sarjanapascasarjana S1 dan non sarjana So, masa kerja terdiri dari $\geq 15$ tahun dan $<15$ tahun

\section{Proporsi Strata}

Berdasarkan strata populasi yang ditetapkan ditentukan proporsi pada strata tingkat pendidikan, masa kerja dengan cara perhitungan sebagai berikut:

1) Strata tingkat pendidikan :

$\mathrm{S} 1=47$ orang : proporsinya

$\mathrm{P} 1=47 / 62=0,76$

$\mathrm{S} 0=15$ orang $\mathrm{q} 1=15 / 62=0,24$ 
2) Strata masa kerja :

$\geq 15$ tahun $=49$ orang

$\mathrm{p}=49 / 62=0,79$

$<15$ tahun $=13$ orang

$\mathrm{q}=13 / 62=0,21$

\section{Pengujian Persyaratan Analisis}

Pengujian persyaratan analisis ini meliputi uji normalitas, uji homogenitas, uji idependensi variabel bebas, dan uji lineritas. selanjutnya akan diuraikan berikut ini :

\section{Data Bersumber dari Sampel yang Dipilih Secara Acak}

Prosedur pengambilan sampel secara acak telah dilakukan sewaktu pemilihan anggota sampel dengan menggunakan teknik stratified proportional random sampling.

\section{Uji Normalitas Data}

Pengujian normalitas dilakukan dengan analisis Chi Kuadrat $\left(\chi^{2}\right)$ terhadap data Kinerja guru, Kreativitas Guru, dan Supervisi Kepala Sekolah. Hasil pengujian normalitas terhadap ketiga variabel tersebut memperlihatkan bahwa probabilitas keliru (p) ketiga $\chi^{2}$ untuk pengujian normalitas tersebut lebih besar dari taraf signifikansi yang digunakan $(\alpha=0,05)$. Jadi $p>\alpha$. Ini berarti bahwa ketiga variabel memiliki data yang berdistribusi normal. Dengan demikian salah satu persyaratan untuk analisis korelasi dan regresi sudah terpenuhi.

\section{Uji Homogenitas}

Pengujian homogenitas ditujukan pada kelompok populasi yang tersebar pada 4 sekolah dan 2 kelompok strata masa kerja guru. Analisis homogenitas variansi kelompok-kelompok ini dilakukan dengan menggunakan teknik Chi kuadrat $\left(\chi^{2}\right)$ Bartlett. Data memperlihatkan dua analisis $\chi^{2}$ memiliki $p>\alpha(0,05)$, maka dapat dinyatakan bahwa variansi data antar kelompok-kelompok populasi tidak berbeda secara signifikan. Dengan demikian dapat disimpulkan bahwa sampel penelitian berasal dari populasi yang homogen. Maka salah satu persyaratan untuk analisis pengujian hipotesis telah pula terpenuhi.

Uji Independensi Antar Variabel Bebas $\left(X_{1}\right.$ dan $\left.\mathbf{X}_{2}\right)$
Uji persyaratan lain yang perlu dipenuhi untuk analisis korelasi dan regresi ganda adalah uji independensi antar variabel bebas yang gunanya untuk memastikan tidak terjadi pembauran (kontaminasi) dalam kontribusi masing-masing variabel bebas terhadap variabel terikat. dapat terlihat bahwa koefisien korelasi $\mathrm{X}_{1}$ dan $\mathrm{X}_{2}$ dengan $p>\alpha(0,05)$. Ini berarti bahwa variabel Kreativitas Guru tidak berkorelasi secara signifikan dengan variabel Supervisi Kepala Sekolah atau independen.

\section{Uji Linearitas Garis Regresi.}

Bila kedua variabel bebas hendak digabungkan dalam analisis regresi ganda, maka garis hubungan masing-masing variabel bebas dengan variabel terikat harus merupakan garis linear. Pengujian linearitas garis regresi yang dimaksud dilaporkan sekaligus sewaktu pengujian hipotesis pertama dan kedua dengan menggunakan analisis regresi linear sederhana.

\section{Hipotesis Pertama}

Hipotesis pertama yang diajukan dalam penelitian ini adalah "Kreativitas Guru berkontribusi terhadap Kinerja guru". Untuk menguji hipotesis ini dilakukan analisis korelasi dan regresi sederhana.

Hasil perhitungan pada menunjukkan bahwa koefisien korelasi antara Kreativitas Guru dengan Kinerja guru adalah sebesar $=0,442$ dengan $\mathrm{p}<\alpha(0,05)$. Berdasarkan hasil perhitungan ini dapat dijelaskan bahwa Kreativitas Guru berkorelasi signifikan dengan Kinerja guru, dan bentuk hubungannya positif, dengan koefisien determinasi $=0,196$.

Selanjutnya, untuk mengetahui bentuk hubungan Kreativitas Guru $\left(\mathrm{X}_{1}\right)$ dengan Kinerja guru (Y), apakah hubungan itu besifat prediktif atau bukan, selanjutnya dilakukan analisis regresi sederhana. Dari hasil analisis pada lampiran 8, diperoleh persamaan regresi $\hat{\mathbf{Y}}=\mathbf{9 3 , 7 9 6}+\mathbf{0 , 5 4 7 X _ { 1 }}$. Kemudian persamaan ini diuji keberartian dan kelinierannya dengan uji F melalui Anova Regresi. Hasil penghitungan menunjukkan bahwa $\mathrm{F}_{\text {Hitung }}=$ 7,304 dengan $\mathrm{p}<\alpha(0,05)$. Ini berarti bahwa model persamaan garis regresi $\hat{\mathbf{Y}}=\mathbf{9 3 , 7 9 6}+\mathbf{0 , 5 4 7 \mathbf { X } _ { 1 }}$ 
signifikan. Kemudian uji linearitas menunjukkan $\mathrm{F}_{\text {hitung }}=1,188$ dengan $\mathrm{p}=0,403$. Jadi $\mathrm{p}>\alpha(0.05)$. Hal ini menunjukkan garis regresi berbentuk garis linear. Ternyata persamaan regresi yang ditemukan signifikan dan linear untuk memprediksi Kinerja guru berdasarkan Kreativitas Guru.

Daya prediksi yang diperlihatkan oleh model regresi di atas ditentukan oleh koefisien arah sebesar 0,547. Ini berarti bahwa setiap peningkatan Kreativitas Guru sebesar 1 skala akan berkontribusi terhadap peningkatan Kinerja guru sebesar 0,547 skala. Sementara nilai Kinerja guru sudah ada sebesar 93,796 skala tanpa Kreativitas Guru. Sebagai contoh, misalkan seorang guru memberikan skor Kreativitas Guru sebesar 100 skala, maka Kinerja guru selanjutnya dapat dapat diprediksi sebesar 100x0,547+93,796=148,796.

Setelah memahami serangkaian analisis di atas, dapat diyakini bahwa hipotesis penelitian yang menyatakan "Kreativitas Guru berkontribusi terhadap Kinerja guru" telah teruji pada taraf kepercayaan $95 \%$.

Selanjutnya, dapat di interpretasikan bahwa faktor Kreativitas Guru memiliki daya prediksi signifikan terhadap Kinerja guru. Kontribusi Kreativitas Guru terhadap Kinerja guru SMP Negeri di Kecamatan Palupuh sebesar 0,196 atau $19,6 \%$.

\section{Hipotesis Kedua}

Hipotesis kedua yang diajukan melalui penelitian ini adalah "Supervisi Kepala Sekolah berkontribusi terhadap Kinerja guru". Untuk menguji hipotesis ini, dilakukan analisis korelasi dan regresi sederhana.Hasil perhitungan menunjukkan, bahwa koefisien korelasi antara Supervisi Kepala Sekolah dengan Kinerja guru adalah 0,408 dengan $p<\alpha(0,05)$. Berdasarkan hasil perhitungan ini dapat dijelaskan bahwa Supervisi Kepala Sekolah berkorelasi positif dan signifikan dengan Kinerja guru, dengan koefisien determinasi 0,166 .

Selanjutnya untuk mengetahui bentuk hubungan tersebut, apakah bersifat prediktif atau tidak, maka dilakukan analisis regresi sederhana. Dari hasil analisis diperoleh model persamaan

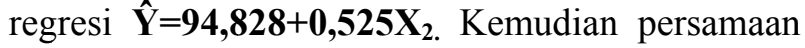
ini diuji keberartian dan kelinearannya dengan uji $\mathrm{F}$ melalui Anova Regresi.

Hasil penghitungan menunjukkan bahwa nilai $\mathrm{F}_{\text {Hitung }}=5,990$ dengan $\mathrm{p}<\alpha(0,05)$. Ini berarti bahwa model persamaan regresi $\hat{\mathbf{Y}}=\mathbf{9 4 , 8 2 8}+\mathbf{0}, \mathbf{5 2 5}_{\mathbf{2}}$ adalah signifikan. Kemudian uji linearitas menghasilkan $\mathrm{F}_{\text {hitung }}=1,364$ dengan $\mathrm{p}=0$,298. Jadi $\mathrm{p}>\alpha(0,05)$. Maka persamaan regresi tersebut adalah linear. Ternyata persamaan regresi yang ditemukan adalah signifikan dan garis regresinya linear.

Daya prediksi ditentukan oleh koefisien arah sebesar 0,525. Ini berarti bahwa setiap peningkatan Supervisi Kepala Sekolah sebesar 1 skala akan berkontribusi terhadap peningkatan Kinerja guru sebesar 0,525 skala. Sementara nilai Kinerja guru sudah ada sebesar 94,828 skala tanpa kontribusi Supervisi Kepala Sekolah. Sebagai contoh, misalkan seorang guru mempersepsi dampak Supervisi Kepala Sekolah senilai 100 skala, maka Kinerja guru selanjutnya dapat dapat diprediksi sebesar 100x0,525+94,828 $=147,328$.

Dengan demikian hipotesis yang diajukan "Supervisi Kepala Sekolah berkontribusi terhadap Kinerja guru" telah teruji secara empiris pada taraf kepercayaan $95 \%$.

Selanjutnya diinterpretasikan bahwa faktor Supervisi Kepala Sekolah dapat digunakan untuk memprediksi Kinerja guru. Berdasarkan hasil analisis di atas dapat disimpulkan bahwa semakin baik Supervisi Kepala Sekolah maka semakin tinggi pula Kinerja guru tersebut. Kontribusi Supervisi Kepala Sekolah terhadap Kinerja guruguru SMP Negeri di Kecamatan Palupuh ditemukan sebesar 0,166 atau $16,6 \%$.

\section{Hipotesis Ketiga}

Hipotesis ketiga yang diuji dalam penelitian ini adalah "Kreativitas guru dan Supervisi Kepala Sekolah secara bersama-sama berkontribusi terhadap Kinerja guru" Analisis untuk pengujian hipotesis ini menggunakan teknik analisis korelasi dan regresi ganda.

Pertama-tama dilakukan analisis korelasi ganda antara variabel Kreativitas Guru dan 
Supervisi Kepala Sekolah dengan Kinerja Guru. Rangkuman hasil analisis korelasi dan uji signifikansinya.

Hasil perhitungan pada Tabel 21 memperlihatkan bahwa koefisien korelasi ganda sebesar 0,550, dan koefisien determinasi sebesar 0,303 dengan $\mathrm{p}<\alpha(0,01)$. Hal ini menunjukan terdapat hubungan yang positif dan sangat signifikan antara Kreativitas Guru dan Supervisi Kepala Sekolah secara bersama-sama dengan Kinerja guru.

Untuk mengetahui bentuk hubungan Kreativitas Guru dan Supervisi Kepala Sekolah secara bersama-sama dengan Kinerja guru, maka dilakukan analisis regresi ganda. Dari hasil perhitungan diperoleh persamaan regresi Kreativitas Guru dan Supervisi Kepala Sekolah secara bersama-sama terhadap Kinerja guru, ditemukan model regresinya

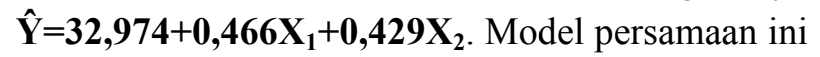
selanjutnya diuji dengan uji $\mathrm{F}$ melalui Anova Regresi.

Hasil penghitungan menunjukkan nilai $F_{\text {Hitung }}$ sebesar 6,298 dengan $p<\alpha(0,01)$. Ini berarti bahwa persamaan regresi ganda $\hat{\mathbf{Y}}=\mathbf{3 2 , 9 7 4 + 0 , 4 6 6} \mathrm{X}_{\mathbf{1}}+\mathbf{+ 0 , 4 2 9} \mathrm{X}_{\mathbf{2}}$ sangat signifikan.

Daya prediksi model regresi yang ditemukan di atas ditentukan oleh koefisien arah X1 sebesar 0,466, dan koefisien arah X2 sebesar 0,429. Ini berarti bahwa setiap peningkatan Kreativitas Guru (X1) sebesar 1 skala akan diikuti oleh penambahan nilai Kinerja guru $(\mathrm{Y})$ sebesar 0,466 skala, dan peningkatan Supervisi Kepala Sekolah (X2) sebesar 1 skala akan diikuti oleh penambahan nilai Kinerja guru (Y) sebesar 0,429 skala. Sebelumnya, nilai Kinerja guru sudah ada sebesar konstanta yaitu 32,974 skala tanpa pengaruh dari kedua prediktor tersebut. Sebagai contoh, misalkan seorang guru mempunyai skor Kreativitas Guru, dan mempersepsi skor Supervisi Kepala Sekolah, masing-masing sebesar 100 skala, maka nilai Kinerja guru itu dapat diprediksi sebesar $100 \times 0,466+100 \times 0,429+32,974=122,474$.

Dengan demikian, hipotesis yang menyatakan bahwa "Kreativitas Guru dan
Supervisi Kepala Sekolah secara bersama-sama berkontribusi terhadap Kinerja guru" telah teruji secara empiris pada taraf kepercayaan 99\%. Ini berarti bahwa model regresi ganda yang ditemukan dapat digunakan untuk meramalkan Kinerja guruguru SMP Negeri di Kecamatan Palupuh, bila skor Kreativitas Guru dan Supervisi Kepala Sekolah diketahui. Besar kontribusinya adalah 0,303 atau $30,3 \%$.

Kontribusi efektif kedua variabel terhadap Kinerja guru sebesar $30,3 \%$ itu bersumber dari Kreativitas Guru sebesar $16,7 \%$, dan dari Supervisi Kepala Sekolah sebesar 13,6\%.

Selanjutnya untuk memeriksa besarnya kontribusi murni masing-masing Kreativitas Guru dan Supervisi Kepala Sekolah terhadap Kinerja guru, dapat digunakan analisis korelasi parsial. Hasil memperlihatkan bahwa terdapat hubungan yang sangat signifikan antara variabel Kreativitas Guru dengan Kinerja guru pada saat variabel Supervisi Kepala Sekolah dalam keadaan konstan, dengan koefisien korelasi sebesar 0,404 dan koefisien determinasi 0,164 dengan $\mathrm{p}<\propto(0,05)$. Hal ini bermakna bahwa peranan Kreativitas Guru terhadap Kinerja guru signifikan meskipun Supervisi Kepala Sekolah dalam keadaan konstan atau tidak ditingkatkan. Kontribusi murninya sebesar $16,4 \%$.

Selanjutnya, koefisien korelasi parsial Supervisi Kepala Sekolah dengan Kinerja guru apabila variabel Kreativitas Guru dalam keadaan konstan adalah 0,365 dan koefisien determinasi 0,133 dengan $\mathrm{p}<\propto(0,05)$ atau signifikan. Hal ini menunjukkan bahwa Supervisi Kepala Sekolah berperan secara signifikan terhadap Kinerja guru meskipun Kreativitas Guru konstan, dengan kontribusi murni sebesar 13,3\%.

Seterusnya untuk mengetahui besaran kontaminasi yang terjadi antar prediktor pada kontribusi bersama Kreativitas Guru dan Supervisi Kepala Sekolah dengan Kinerja guru dilakukan proses perhitungan selisih antara kontribusi efektif masing-masing prediktor dengan kontribusinya secara parsial. Besarnya kontribusi efektif Kreativitas Guru terhadap Kinerja guru sebesar 
$16,7 \%$ sedangkan kontribusinya secara parsial sebesar $16,4 \%$. Dengan demikian terjadi perbedaan $0,3 \%$. Hal ini menunjukkan bahwa kontaminasi Supervisi Kepala Sekolah kepada prediktor Kreativitas Guru sebesar 0,3\%. Kontaminasi ini relatif kecil dan dapat diabaikan karena kedua prediktor teruji independen.

Selanjutnya kontribusi efektif Supervisi Kepala Sekolah dengan Kinerja guru sebesar $13,6 \%$ dan kontribusinya secara parsial sebesar $13,3 \%$. Dengan demikian terjadi perbedaan sebesar $0,3 \%$. Hal ini menunjukkan adanya kontaminasi Kreativitas Guru kepada prediktor Supervisi Kepala Sekolah sebesar 0,3\%, namun sangat kecil dan dapat diabaikan.

\section{SIMPULAN DAN SARAN Simpulan}

Berdasarkan hasil penelitian yang meliputi tiga variabel yaitu variabel Kreativitas Guru $\left(\mathrm{X}_{1}\right)$, Supervisi Kepala Sekolah $\left(\mathrm{X}_{2}\right)$, dan Kinerja Guru (Y) di SMP Negeri Kecamatan Palupuh, Kabupaten Agam bahwa ketiga hipotesis penelitian yang diajukan dapat diterima kebenarannya secara empiris, dan disimpulkan sebagai berikut:

1. Kreativitas Guru-guru di SMP Negeri Kecamatan Palupuh berkontribusi terhadap Kinerja mereka sebesar $19,6 \%$. Ini berarti bahwa peningkatan kinerja guru dapat dilakukan melalui peningkatan kreativitas guruguru.

2. Supervisi Kepala Sekolah berkontribusi terhadap kinerja guru di SMP Negeri Kecamatan Palupuh yaitu sebesar 16,6\%. Ini berarti bahwa peningkatan kinerja guru dapat dilakukan secara sistematis dan terprogram melalui peningkatan intensitas Supervisi oleh Kepala Sekolah.

3. Kreativitas Guru dan Supervisi Kepala Sekolah secara bersama-sama memberikan kontribusi terhadap kinerja guru SMP Negeri Kecamatan Palupuh sebesar 30,3\%. Ini berarti bahwa peningkatan kinerja guru dapat dilakukan melalui peningkatan supervisi oleh kepala sekolah sembari menumbuh kembangkan daya kreativitas guru dalam pelaksanaan tugastugasnya.

4. Tingkat capaian Kinerja Guru SMP Negeri Kecamatan Palupuh termasuk kategori cukup yaitu $78 \%$ dari skor ideal, dan Supervisi Kepala Sekolah kepada guru-guru termasuk kategori cukup yaitu 78,6\% dari skor ideal, sedangkan Kreativitas Guru-guru termasuk kategori baik yaitu $84 \%$ dari skor ideal.

\section{Saran}

Berdasarkan temuan dan implikasi penelitian di atas peneliti menyampaikan beberapa saran sebagai berikut:

1. Guru-guru diharapkan dapat menyadari tugas dan kewajibannya sebagai tenaga profesional dalam bidang pendidikan. Persiapan mengajar merupakan suatu keharusan bagi seorang guru sebelum melaksanakan tugas. Guru harus mampu kreatif menciptakan model-model pembelajaran yang membuat siswa aktif dan suasana belajar yang kondusif serta menyenangkan

2. Pelaksanaan supervisi oleh kepala sekolah perlu dilakukan secara terus menerus sehingga segala permasalahan yang timbul bisa segera diantisipasi. Hal ini dapat dilakukan melalui observasi dan kunjungan kelas sehingga dapat memberikan bimbingan dan perhatian terhadap guru yang kurang mampu.

3. Kepala sekolah, guru dan warga sekolah lainnya agar selalu menciptakan lingkungan kerja yang kondusif, saling menghargai, saling mendukung, saling pengertian dan keterbukaan sesama warga sekolah.

4. Para pengambil kebijakan, Dinas Pendidikan Kabupaten Agam khususnya diharapkan dapat memfasilitasi kegiatan-kegiatan yang berkaitan peningkatan profesionalisme guru seperti pelatihan, workshop dan pembinaan-pembinaan melalui DIKLAT, KKG, MGMP maupun MKKS.

5. Peneliti selanjutnya agar lebih memperluas kajian tentang kebehasilan kinerja guru dari segi aspek-aspek lain karena diduga masih banyak 
faktor lain yang memberikan sumbangan yang signifikan terhadap kinerja guru yang belum terungkap dalam penelitian ini.

\section{DAFTAR PUSTAKA}

Arikunto, Suharsimi, 1988, Organisasi dan Administrasi Pendidikan Tekonologi dan Kejuruan, Jakarta: Depdikbud ,P2LPTK 1990, Prosedur Penelitian, Suatu Pendekatan Praktis, Jakarta: Rineka Cipta 2004, Dasar-dasar Supervisi, Jakarta: Rineka Cipta
Anoraga , Panji, 1992. Psikologi Kerja, Jakarta : Rineka Cipta

Imron, Manan, 1989. Dasar-dasar Sosial Budaya Pendidikan, Jakarta: Depdikbud

Munandar,Utami ,1994, Memupuk Bakat dan Kreativitas Siswa Sekolah Menengah, Jakarta, Gramedia

(2004) Pengembangan Kreativitas Anak Berbakat,Jakarta, Rineca Cipta ( 1999) Kreativitas dan Keberbakatan, Jakarta: PT Gramedia Pustaka Utama 